\title{
Poultry waste generation, management and the environment: a case of Minna, North Central Nigeria
}

\begin{abstract}
To develop an acceptable manure management and pollution prevention plan in poultry production, accurate accounting of waste generation and nutrient concentration of the waste need to be ascertained. In view of this, a field study was conducted in Minna, Nigeria to assess quantity of waste generated and the quality of the wastes in selected registered poultry farms in the town. This is with a view to knowing present waste generation status and managements strategies with respect to environmental protection and to recommend appropriate management methods if the present practice is not acceptable. Questionnaires focusing on farm information, birds' information and waste management were administered in the farms. Fresh poultry waste samples (manure) were collected from layer, broiler and cockerel sections of three of the selected farms at birds growth stage of 6 and 12 weeks respectively. The samples were analyzed for nitrates, phosphates and bacteriological parameters. Findings from the questionnaires showed that a total of 2,131,400 layers, $1,224,840$ broilers and 848,570 cockerels which amount to a total of 4,204,810 birds are raised annually in confinement in the farms covering an area of 170 hectares of land. From calculation, the farms generate 100.97 metric tons of dead birds over a brooding cycle with about 26,565 metric ton of waste excluding slaughter house litter and hatchery wastes. Laboratory analysis results showed that the waste samples contain values as high as $206.75 \mathrm{mg} / \mathrm{g}$ and $34.21 \mathrm{mg} / \mathrm{g}$ of nitrates and phosphates respectively. Bacteriological values recorded are $25767.21 \mathrm{cfu} / 100 \mathrm{mg}, 48214 \mathrm{cfu} / 100 \mathrm{mg}$ and $17647.9 \mathrm{mg} / \mathrm{g}$ for faecal coliform, total coliform and faecal streptococci respectively. Management of the waste is poor in the farms visited as indiscriminate dumping on land and burning are major waste management systems in these farms. Only a few adopt re-feed method, dead birds are buried without minding the shallow water table of the area. None of the farm visited adopt modern green disposal as waste management strategy. This waste generation and management method need to be changed to safe Minna environment from imminent hazards. It is therefore recommended that the poor management system of land application should be replaced with modern management strategy like green disposal, gasification, composting and re-feeding. These methods are more environmental friendly and can generate of resources from the waste.
\end{abstract}

Keyword: Environmental protection; Green disposal; Manure management and poultry farms 